ISSN: 2146-7765
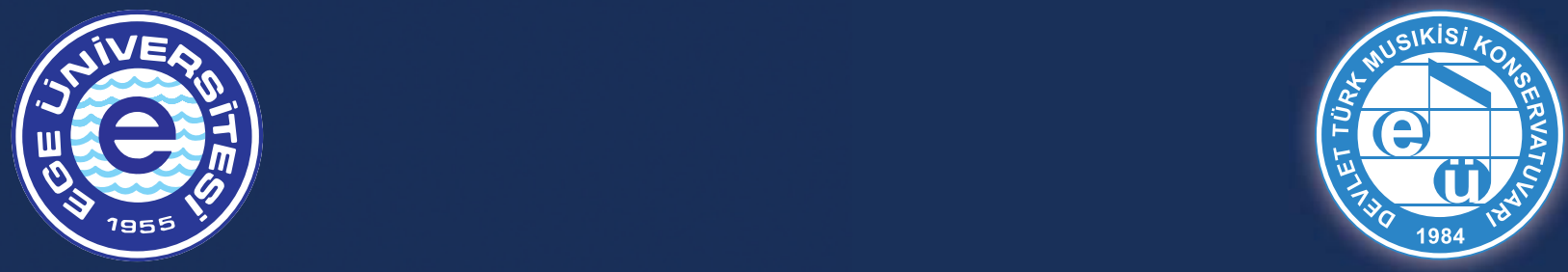

\title{
Ege Üniversitesi
}

Devlet Türk Musikisi Konservatuvarı Dergisi

Ege University

Journal of Turkish Music State Conservatory

Sayı: 11 - Aralkk 2017 


\title{
MÜZIKTE TÜR KAVRAMI: MÜZIK TÜRLERi SINIFLANDIRMASINDA YENI BİR MODEL ÖNERISI
}

\author{
The Concept of Genre in Music: A New Model Suggestion \\ for the Classification of Music Genres
}

IIhan ERSOY*

\begin{abstract}
Öz
İnsanoğlu, yaşam sürecinde karşılaştığı kimi kaosları önce anlamlandırabilmek ve bu kaoslardan kurtulabilmek için bir düzene ihtiyaç duyar. Bu düzen ihtiyacı belirlenen bir ya da birkaç ölçütün yardımıyla giderilir. Bilimsel zeminde kaosun bir düzene dönüştürülmesine yönelik en temel çaba "sınıflandırma"dır. Bir araştırmaya konu olan olgu ya da olgular önce sınıflandırılır; daha sonra diğer olgu ya da olgular ile bir ilişkisellik (relationality) çerçevesinde irdelenir.

Müzik, bir fenomen olarak bilimsel bir çerçevede irdelenebilir. Eğer amaç bu ise, müzikte var olan kaosu kozmosa dönüştürebilmek ve müzik fenomenini anlamlandırabilmek için sınıflandırma vazgeçilmez bir zorunluluktur. Müzik gerçekten karmaşık bir fenomendir. Müziksel bir sınıflandırmada müziğin tüm bileşenlerinin ve süreçlerinin dahil edilmesi yerinde olur. Dolayısıyla müzikleri sınıflandırırken, monolojik ve indirmeci bir yaklaşım yerine; sınıflandırmalarda çok ölçütlülük ve ilişkisellik yer almalıdır. Bu makalede müzik sınıflandırmalarına yönelik bu çerçevede yeni bir model önerilmektedir. Bu öneri ile temel amaç, monolojik ve indirgemeci yaklaşımlardan uzak kalınarak -olabildiğince- tutarlı ve nesnel ölçütler üzerinde inşa edilmesine yöneliktir.
\end{abstract}

Anahtar Kelimeler: Biçim, form, müzik, sınıflandırma, tür.

\begin{abstract}
Mankind needs an order to be able to first understand and to get rid of some of the chaos that he encounters in his life cycle. This need for order is addressed with the help of one or more specified measures. The most fundamental effort to scientifically transform chaos into order is "classification". A phenomenon or phenomena subject to a research study are classified first; then they are examined within the context of relationality with other phenomenon or phenomena.

Music can be examined as a phenomenon in a scientific framework. If this is the goal, classifying is an indispensable necessity to be able to transform the chaos that exists in music into the cosmos and to understand the music phenomenon. Music is a really complicated phenomenon. In a musical classification, it is appropriate to
\end{abstract}


include all the components and processes of music. Therefore, while classifying music, multi-criteria and relationality should take place in classifications instead of a monologic and reductionist approach. In this article, a new model is proposed in this framework for music classifications. With this proposal, the main goal is to build on consistent, objective criteria, as far as possible, while staying away from monologic and reductionist approaches.

Keywords: Classification, form, genre, music, style.

\section{Giriş}

Antropolojiden kuramsal ve kavramsal ödünçler yoluyla disiplinleşen etnomüzikoloji, ilk dönemlerden itibaren benzerliklerden daha çok çeşitliliklere, farklılıklara yönelik bir ilgi göstermiş ve bu ilgi onun temel çalışma odağını oluşturmuştur. Burada bu ilgi ile amaçlanan şey, farklılık içeren kültürlerin ve dolayısıyla müziklerin arasındaki ilişki düzeylerini anlama spektrumunun önündeki engellerin kaldırılmasıdır.

Müzik, ontolojisi bakımından her ne kadar homojen olarak kabul edilse de karmaşıklık ve çeşitlilik içeren “heterojen” bir bütündür. Müzikteki bu karmaşıklığı ve çeşitliliği analitik bir düzleme çekerek irdelemek ve kavrayabilmek bakımından "tür" kavramı işlevseldir. Müziği tür kavramıyla ele almak, müziğin dünya üzerindeki çeşitliliğinin kabulü anlamına da gelir. Dolayısıyla bu çerçevede bir ele alış, müziğin çeşitliliğini kabul etmekle birlikte, aynı zamanda bu çeşitliliği oluşturan her bir müzik türünün ilgili ölçütler üzerinden farklı anlamlar ürettiğini de ortaya koyar.

\section{Tür Kavramı}

Tür ${ }^{1}$, genel-geçer bir yaklaşımla; "ortak özellikleri olan unsurların bir araya gelerek oluşturdukları birliktelik" olarak tanımlanabilir. Yani tür kavramının, birbirleriyle bağlantılı olan olguların oluşturduğu bütünü/kümeyi çağrıştıran bir anlamı vardır. Bir başka deyişle tür, aralarında yeterli nitelik uyarlılıkları gösteren, bir çatı altındaki yapıtların oluşturduğu bir bütündür. Tür sözcüğü işlevsel bakımdan hem "dahil etme/içerme", hem de "hariç kılma/dışlama" görevi üstlenmiştir. Yani, sınıflandırma ediminin ortaya çıkardığı tür, "... karşıtlık ve dahil olma ilişkisine dayanan bir çözümlemedir" (Özbudun, Şafak, \& Altuntek, 2007: 252-253).

Tür, kendi içinde farklı "düzeyler silsilesi" barındıran bir kavramdır. Dolayısıyla tür kavramını sonsuz olmayan bu çoklu düzey içinden, ilgili alan için belirlenmiş sınırlar çerçevesinde ele almak daha doğru olur. Genel-geçer bir yaklaşımla temel özellikler ekseninde benzeşme ve özdeşlik bakımından kapsayıcı olan türleri "Temel (ana) Tür"; bu temel tür kapsayıcılığı ve bağlayıcılığı altında, kendi içindeki farklılaşan türleri de "Alt (yaratı) Tür" olarak değerlendirmek doğru olacaktır.

\footnotetext{
${ }^{1}$ Form kavramı ile tür (genre) kavramları çoğu zaman birbirlerinin yerine kullanılır. Ancak bu makalede tür kavramı şekil/biçim anlamına gelen form kavramını da kapsayan daha genel bir ifade olarak ele alınır.
} 
Bir düzeyin "temel tür" olarak kabul edilmesindeki normatif gereklilik, ilgili düzeyin altında bir başka düzeyi ya da düzeyleri, yani alt türleri barındırma kapasitesinin varlığıdır. Bir başka ifade ile bir düzey, ancak alt tür yaratma potansiyeli taşıyorsa temel tür olarak kabul edilebilir. Dolayısıyla türlerin düzeyler bakımından alternatifli bir yapı barındırdığını ve temel alınan konu ve düzey bakımından farklı sonuçlar üretebileceklerini unutmamak gerekir.

$\mathrm{Bu}$ teorik açıklamayı daha anlaşıı olması bakımından örneklendirelim; "Yaşamak", canlı türlerinin benzeşme ve özdeşlik bakımından ortak ve temel özelliğidir. Yaşamak, canlı türünü belirlerken, bu düzeyin altında birbirlerine göre farklılaşan kimi canlı türlerini de barındırır. Dolayısıyla canlı olmak/yaşam sürmek bir temel tür dinamiği ise; bu düzeyin altında yer alan farklı canlı türler de birer alt tür olarak değerlendirilebilir. Elbette bu alt türlerde de yaşamak ortak bir zemindir. Ancak her yaşayan/canlı, özdeş/homojen değildir ve aralarındaki kimi farklılıkları ortaya koyabilmek adına alt tür kavramına ihtiyaç duyulur.

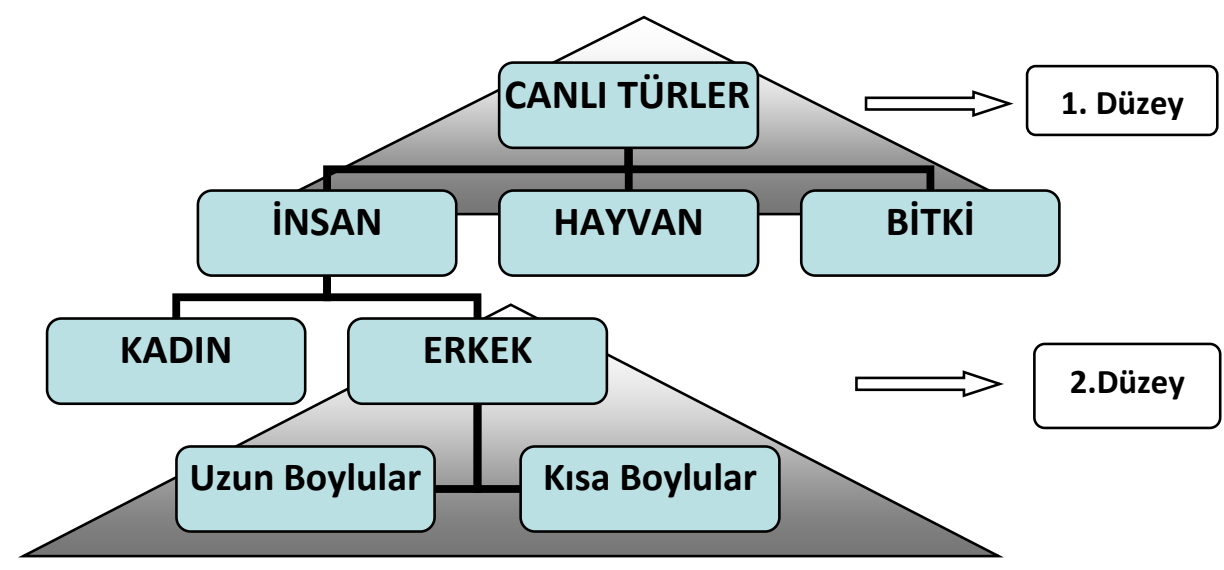

Şekil 1: Tür Tasnifinde Düzey Örneği

Yukarıdaki tabloda görüleceği üzere birinci düzeyde "canlı" olmayı temel bir tür olarak ele alırsak, "Insan"; "Hayvan" ve "Bitki" bir alt tür konumuna düşer. Dolayısıyla burada canlı, bir temel tür; insan ise (hayvan ve bitki gibi) bir alt türdür. Ancak ikinci düzeyde, bir alt düzey yaratma potansiyeli ile insanı temel tür olarak ele alabilir; cinsiyet bağlamında "kadın" ve "erkek" olarak iki farklı alt türe ayırabiliriz. Bu alt tür üretme potansiyeli ölçütleri çeşitlilik arz edebilir: yaşam süreleri bağlamında "yaşlı" ve "genç" gibi; ya da uzunluklarına göre "uzun boylular" ve "kısa boylular" gibi.

Esasen, sınıflandırmaya temel olan sınırlılıkları belirlemek, ilgi alanımızı daha nesnel bir biçimde belirlememize ve ele almamıza yardımcı olacaktır. Dolayısıyla 
burada söz konusu olan bu çoklu düzey içinden ilgi alanımızı, sınırları belli bir çerçevede; temeli oluşturacak biçimde bir kesit olarak belirlenmek son derece önemlidir.

\section{Sınıflandırma Edimi Hakkında}

Anlamaya ilişkin ilk ve temel yaklaşım sınıflandırmadır. Çünkü anlaşılmaya çalışılan nesne, olay ya da olgu öncelikle belirli bir düzenlilikte ele alınmalıdır. Daha basit bir ifade ile, bilmek için sınıflandırma bir gerekliliktir. Dolayısıyla "sınıflama bilginin koşuludur (Soykan 2012: 54)". Bilgi üretim çabası olarak bilimsel araştırma, belirli süreçlere tabidir. "Radcliffe-Brown bilimsel araştırmada "Gözlem; Sınıflandırma ve Genelleştirmeler" olarak üç aşamanın olduğunu vurgularken sınıflandırmayı da bu aşamalardan biri olarak ele alır (Kenny \& Smille 2015: 63)". Sınıflandırma bilimsel incelemenin temelini oluşturur. Bu nedenle "herhangi bir bilim kolunda ilk adım olarak inceleme konusu nesne ve olguları inceleme amacımıza uygun sınıflamak (Yıldırım 2010: 87)" bir zorunluluktur. Ancak ölçüt ya da ölçütler olmadan herhangi bir sınıflandırma mümkün değildir. Sınıflandırma, belirlenmiş ölçütler sistemi üzerine inşa edilmelidir.

Sınıflandırma, genel-geçer bir tanımla; bireylerin sosyal ve fiziksel çevrelerini kategorilere ayırmasını ve çeşitli öğeleri bu kategorilere yerleştirmesini ifade eden bilişsel bir süreçtir. Bir başka deyişle sınıflandırma, insanın çevresini, kategoriler halinde düzenleme etkinliği ya da sürecidir. Söz konusu kategoriler, bireyin eylemleri ve tutumları bakımından birbirleriyle özdeş, eşdeğer ve birbirine benzer gördüğü olgu, insan, eşya, olay grupları ya da bunların belirli niteliklerini kapsayan gruplandırmalardır. Sınıflandırma süreçleri, bireyin yaşamı açısından bir dizi pratik işleve sahiptir. Sınıflandırma, ilk olarak dünyanın karmaşıklığını azaltmaya yarar. Dolayısıyla sınıflandırma edimi bireyin çevresini basitleştirip sistematikleştirmesine katkıda bulunarak dünyayı anlamasını ve dünyadaki değişikliklerle başa çıkmasını mümkün kılar. İkinci olarak karşılaşılan uyaranların, tanınmasını ve bir düzen içine konmasını; çevreyi bölümlemeyi ve bir açıdan benzer, bir başka açıdan farklı görülen öğeleri bir araya toplamayı sağlar. Böylece anlamlı, öngörülebilir bir dünyanın bilişsel olarak inşasını kolaylaştıı (Bilgin 2003:190). "Kategoriler yoksa düşünce de yok" der Arslan ve ekler: "kategoriler düşüncenin paha biçilmez araçlarıdır (Arslan 2007: 47)".

Bilimsel irdelemelerde sınıflandırmanın önemli bir yer tuttuğu konusunda herhangi bir itilaf yoktur. Sınıflandırma edimi, bilimsel literatürde bir amaç ve zorunluluk olarak görülmesinin yanında faydalarına yönelik görüşlere rastlamak da mümkündür. Dolayısıyla esasen belki de bu fayda onu gerekli ve zorunlu kılmaktadır. Arslan sınıflandırmanın keyfi olduğunu söylese de faydalı olduğunu aktarır: "Şüphesiz bütün sınıflandırmalar bir bakıma yapay ve keyfidirler. Ancak onlar zihnimizde bir düzen kavrayış ve anlatımımıza kolaylık getirirler (Arslan 2009: 165)". Kneller de bu minvalde görüş bildirir: "Sınıflandırmanın amacı enformasyonu organize ederek 
hafızaya yardım etmek ve her şeyden önce nesnelerin ve olayların yapısını ve ilişkilerini onlar hakkında genel önermeler oluşturabilecek şekilde tanımlamaktır (Akt: Arslan 2007: 49)". Egon Fridell sınıflandırma için şunları söyler: “... sıradan bir akıl yürütme bile gösterir ki sınıflandırmalar yararlı, zorunlu ve her şeyden önce kaçınılmazdır, çünkü düşünüş tarzımız doğuştan sınıflandırma eğilimi içindedir (Akt: Berendt 2003: 13)". Şerif Mardin, "etrafımızdaki alemi sınıflandırmadan yaşamamız mümkün değil" der ve sınıflandırma yapmanın zorunluluğu ve yararına ilişkin şöyle bir örnek verir: "Şu gördüğüm pırıl pırıl parlayan koyu lacivert renkte dikenli çalının içinden gözüken küçük tomurcuk, böğürtlen galiba, kuşku duymadan yiyebilirim. Fakat şu diğer çalının üzerindeki kırmızı tomurcuğun zehirli bir meyve olduğunu bana öğrettiler. Onu böğürtlenle eş tutarsam ölürüm (Akt: Berendt 2003: 98)". Mardin'den yapılan bu alıntı, sınıflandırmanın kimi zaman insan hayatı için bile önem taşıdığını vurgular. Elbette müzikteki sınıflandırma insan için "hayâti" bir mesele değildir. Ancak bu tip bir sınıflandırma müziğin algılanması, anlamlandırılması, üretilmesi, tüketilmesi ve öğretilmesi gibi içinde birçok farklı kulvar barındıran bir süreç için fayda sağlayacaktır.

Yukarıda da bahsedildiği üzere bir görüngünün temel bir tür olarak kabul edilmesinde temel veri, ilgili görüngünün alt türlerine sahip olup-olmadığıdır. Yani eğer bir görüngü, alt tür yaratma potansiyeli taşıyorsa bu o görüngünün temel bir tür olarak kabul edilmesi için yeterli ve aynı zamanda gerekli bir sonucudur. Buradan hareketle, müzik odaklı bir yaklaşım ile müziğin temel bir tür olarak ele alınmasında herhangi bir beis yoktur. Çünkü müzik, yarattığı etki alanı içinde kimi ortak özellikler ile alt türleri bünyesinde barındırma kapasitesi taşır. Alanımızın temeli müzik ise, müzikte temel türleri belirleyebilir, bu temel türlere bağlı olan alt türleri de belirleyebiliriz. Buradaki hareket noktası makalenin bütününde vurgulandığı üzere öncelikle ölçütlerin belirlenmesi ve daha sonra bu ölçütler üzerinden tür özeliklerinin açıklanması olacaktır.

\section{Temel Bir Tür Olarak Müzik}

Müzik çok boyutlu ve oldukça hacimli bir fenomendir. Dolayısıyla buradan hareketle Erol'un da vurguladığı gibi, "müzikten değil, müziklerden söz etmek (Erol 2009: 23)" daha açıklayıcı olacaktır. Çünkü bir gerçeklik olarak müzikler çeşitlilik arz eder. Müzikteki bu çeşitliliğin belirli bir sistematik ile ele alınması, müziğin daha iyi anlaşılmasında ve anlatılmasında yarar sağlayacaktır.

Timothy Rice'ın "Etnomüzikolojinin Yeniden Şekillenmesine Doğru" adlı makalesinde kullandığı bir ifade dikkat çekicidir: "Farklı gibi görünen müziklere, farklı bakış açıları uygulandığında, bütün müzik türleri hakkında nasıl öğretim yapılabilir? (Rice 2002: 137)". İşin doğrusu, dünya üzerinde, sınırsız müzik türü vardır. "Biz müzik bilimcileri ve eğitimcileri olarak bu kaotik ortamı, kozmosa nasıl dönüştürüp, öğrencilerimize nasıl ve hangi paradigmalar çerçevesinde aktarmalıyız?" sorunsalı, gerçekten en temel meraklardan biridir ve bu makalenin de çıkış noktasıdır. 
Müziksel çeşitliliğin normatif ve sistematik bir model üzerinden ele almak özellikle günümüz iklimde hiç de kolay bir iş değildir. Günümüzde, teknolojik destekli müzik endüstrisinin gelişmesi ile müziklerin sınırlarının belirsizleşmesi ile "saf"/"arî" bir müzik türüne rastlamak hemen hemen olanaksızlaşmıştır. Postmodern dönemin normlarından bakıldığında müzikler oldukça girift ve melez (hibrit/syncretic) bir yapıdadır. Bu dönemde çatışmanın ve aynı zamanda dayanışmanın olmadığı bir toplum bulmak ne kadar zor ise, toplumsal bir fenomen olan müzikte de durum bir o kadar zordur. Dolayısıyla müzik, içinde birçok bileşen barındıran bir fenomen olarak tanımlanması kadar, sınıflandırıması da zordur. Ancak elbette müzik, bir biçimde kategorilere bölünebilir, bu mümkündür. Oluşturulan bu kategorilerin temel dinamiklerinin ne olduğu, yapılan sınıflandırmadaki ölçütlerin neler olduğu, yani sınıflandırmanın belirli bir sistematiğinin olup-olmadığı ilgili sınıflandırmanın niteliğini ortaya koyar.

\section{Literatürde Yer Alan Kimi Müzik Sınıflandırmaları}

Sınıflandırma yapmak, temelde çok basit bir iş gibi görünebilir. İnsanlar için; "kısa boylular - uzun boylular"; "erkekler - kadınlar" ya da "sarışınlar - esmerler" gibi sınıflandırmalar yapmak mümkündür. Ancak kesin bir görüngü için buradaki her bir sınıflandırma, farklı ölçütler üzerinden gerçekleştirilmiştir. Illk sınıflandırma örneğinde uzunluk ölçütü; ikinci sınıflandırma örneğinde cinsiyet ölçütü; üçüncü sınıflandırma örneğinde ise renk ölçütü belirleyici olmaktadır. Bu örnekten hareketle, bir erkek ile bir kadının aynı boyda (uzunlukta) olması, cinsiyet ekseninde farklılaştırmalarına rağmen onları uzunluk ölçütü ekseninde aynı kategoride konumlandırır. Dolayısıyla bu tip ölçüt değişkenleriyle hareket edildiğinde bir ölçüt iki farklı olguyu kimi zaman özdeşlik/benzerlik/aynılık olarak konumlandırırken, bir başka ölçüt ise iki benzer olguyu farklılaştırabilmektedir.

Sınıflandırmada amaç farklılıkları ve özdeşlikleri tespit edip, gruplamaktır. Buna hizmet eden işaretleme sistemine Nominal Ölçek adı verilir. Nominal ölçek; farklı kümeleri birbirinden ayırmaya yararken, aynı zamanda benzerleri aynı grupta toplamaya yarayan bir tanıtlama, adlandırma amacına hizmet eder. Dolayısıyla bu makale çerçevesinde sınıflandırmaların diğer bir sınıflandırma yöntemi olan ordinal bir ölçek dahilinde oluşturulmadığını vurgulamakta yarar var. Müziksel yazında yer alan sınıflandırmalarda en sık karşılaşılan problem, sınıflandırmaların hangi dinamikler bağlamında ve hangi ölçütlere göre oluşturulduğunun belirsizliği, önem ve değer gibi duygu bağımlısı kavramlar yoluyla; yani daha çok ordinal bir yaklaşımla ortaya konulmuş olmasıdır.

Konuyla ilgili olarak literatürde yer alan tüm sınıflandırmalara değinmek makalenin hacmini aşacağı için, seçilmiş olan bazı sınıflandırmalar konuya ilişkin fikir

\footnotetext{
${ }^{2}$ Ordinal ölçek; nesne ya da olguların, derecelendirilmeleri, önem ve değer yönünden farklılıklarını ortaya koymaya çalışılırken kullanılan bir yöntemdir.
} 
verecektir. Illk önce ölçütten bağımsız bir biçimde yapılan sınıflandırmalara bakalım: Örneğin Bulanık, ölçütleri belirlemeden, tartışmadan, doğrusu nasıl bir perspektif ile sınıflandırdığı da anlaşılamayan çarpıcı bir müzik sınıflandırması yapar. Bulanık'a göre müzikler: "Dinsel Müzikler"; "Dünyada Belli Başı Müzik Çeşitleri" ve "Notalama Sistemleri" olarak üç temel başlık altında sınıflandııımıştır (Bulanık 2005: 2). Bir başka örnek olarak Uçan'a göz atalım. Uçan'ın sınıflandırmasında belki ilk dört maddesine bakıldığında zamansal/dönemsel dinamik olarak standart bir ölçüt belirlenmiş gibi görünse de; sınıflandırma içinde yer alan beşinci maddenin bu ölçüte nasıl dahil edildiği belirsizdir:

1. Geleneksel Türk Halk Müziği

2. Geleneksel Türk Sanat Müziği

3. Yeni/Modern (çağdaş) Türk Sanat Müziği

4. Yeni/Modern (çağdaş) Türk Halk Müziği

5. Uluslararası (sanat, halk, popüler) müzikler (Uçan 2005: 112)

Canbay'ın yapmış olduğu sınıflandırmanın da ölçütleri ve dinamiklerini tespit etmek son derece güçtür:

1. Türk Halk Müziği

2. Türk Sanat Müziği

3. Askeri Müzik

4. Popüler Müzikler

5. Klasik Müzik

6. Dini Müzik (2015: 201)

Vahid Lütfi Salcı'nın sınıflandırma yaparken, hangi ölçütü/ölçütleri kullandığını tespit etmek son derece güçtür. Salcı, (Türkiye'de var olan) müzikleri aşağıdaki gibi sınıflandırmıştır:

1. Osmanlı pasaportu verilmiş ve Türk etiketi yapıştırılmış (Şark musikisi),

2. Garp musikisi,

3. Başta Mevleviler olmak üzere Rufai ve Kadiri gibi tarikatların kullandıkları (şehir açık tekke musikisi),

4. Şark musikisinden müteessir olan şehir Bektaşilerinin kullandıkları (şehir gizli tekke musikisi),

5. Köylerdeki Mevlevi, Rufai ve Kadiri tarikat mensuplarının şark musikisinin biraz daha basitleştirilmiş şekli olan (köy tekke musikisi),

6. Mevzuumuzla sıkı sıkıya alakadar olan ve öz Türk musikisi sinesinde yaşayan (açık halk musikisi),

7. Dava ve mevzuumuzu ifade eden (gizli halk musikisi), 
8. İçimize sonradan girmiş olmakla beraber halk tarafından pek çok şükran ve minnetlerle karşılanan ve zaman zaman hepimizi milli havalar ile ağlatmış bulunan (Şark ve Garp musikisi ile karışık halk musikisi), "bandolar",

9. Tatlı bir bela gibi sonradan başımıza musallat olan (caz musikisi) (folkloredebiyat.com, 02.10.2017)

Ölçütsüzlüğün dışında, belirlenmiş olan "bir" ölçüt üzerinden yapılan sınıflandırma, sıklıkla rastlanır bir tercihtir. Bu tip tek bir ölçütlü sınıflandırma yapmak elbette mümkündür ve kısmen kabul edilebilir. Yalnız bu tip bir sınıflandırmanın sınırlı bir sonuç yarattığı bilincinde olmak gerekir. Bu tip bir sınıflandırma, var olan bütünselliği yalnızca iki farklı alana böler. Burada müzikler iki taraflı ve birbirlerine karşıt şeyler biçiminde düşünülür. Ayrıca bu tip sınıflandırma dahilinde, müzikte var olan çeşitliliğin çoğu görmezden gelinir ve sınıflandırmada düşünce merkezimize yerleştirdiğimiz bir olgu, müzikte temel bir sınıflandırmaya olanak sağlar. Örneğin,

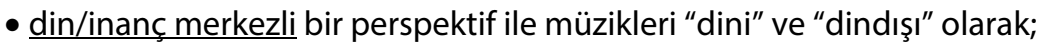

- teknik ve ses kaynakları bakımından "sözlü/vokal" ve "sözsüz/çalgısal" olarak;

- takvimsel, kronolojik bir yaklaşımla "geleneksel" ve "çağdaş" olarak;

- estetik bir yaklaşımla "güzel/iyi" ve "çirkin/kötü" olarak;

- ulusalcı bir yaklaşımla da "ulusal" ve "uluslararası" müzikler gibi.

Burada temel bir problematik, kimi müzik türlerinin hem dini; hem de din dışı müzik türleri olarak sınıflandırabilme potansiyelleridir. Örneğin, taksim hem dini müziklerde hem de dindışı müziklerde kullanılan ve her iki müzik sınıflandırılmasında da yer alabilen bir müziksel türdür. Bu biçimde, sadece tek bir ölçüte dayalı sınıflandırmalarda bir başka problematik ise; bilinçli olarak ya da bilinçsiz olarak eksen daraltılır ve kimi bileşenler yoluyla birbirilerinden oldukça farklı olan müzikler aynılaştırılır. Bu yaklaşım, dindışı olması nedeniyle "şarkı", "marş" ve "zeybek" türlerini aynı zeminde konumlandırır. Oysa adı geçen türler, birbirlerinden başka bileşenler yoluyla keskin bir biçimde ayrışırlar.

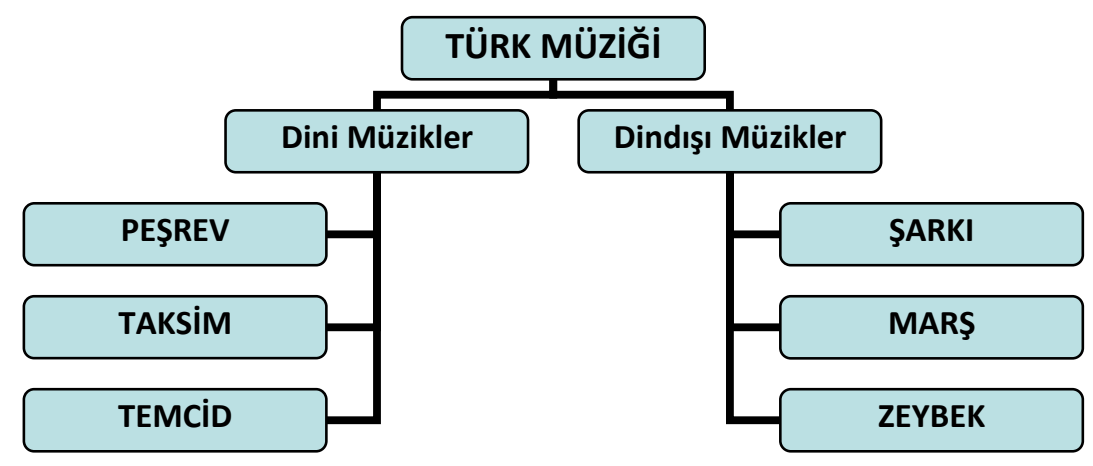


Türk müzik literatüründeki sınıflandırmalarda da bu tip bir yaklaşımın, yani tek ölçütlü bir sınıflandırmanın hakim/yaygın olduğunu söylemek pek yanlış olmayacaktır. Bir çok kaynak, oluşturduğu "bir" ölçüt dahilinde Türk müzik kültürünü sınıflandırmaya yönelir. Burada belirlenen tek ve hakim ölçütün de genel ve yaygın olarak inanç/din ekseninde gerçekleştirildiğini görüyoruz. Örneğin: Yücel, kitabının hemen başında bir sınıflandırma ihtiyacından bahseder ve din merkezli bir sınıflandırma yapar. Bu sınıflandırma, Türk müziğini "dindışı (seküler) müzik" ve "dini müzik" olarak iki farklı kulvarda ele alır (Yücel 2007: 1). Buna paralel olarak Say da aynı ölçüt ile, Türk müzik geleneğini iki alanda inceler: "Dinsel müzik" ve "Din dışı müzik" (Say 2008: 243).

Tek ölçütlü müzik sınıflandırmaları hâkim olsa da Türk müzik literatürü, yalnızca inanç merkezli bir sınıflandırma ile sınırlı değildir. İnanç merkezli dışında, belirlenmiş olan farklı birçok unsur, tek ölçüt olarak kullanılmıştır. Soykan, müziği "aşağı müzik" - "yukarı müzik" olarak iki farklı biçimde kategorize ederken, temel ölçüt olarak melodiyi ve armoniyi merkeze koyar. Soykan'a göre, hiçbir melodi ve armoniye sahip olmayanlar aşağı; melodi ve armoniye sahip olanlar ise yukarı müziktir. Soykan'a göre aşağı müzik bedeni; yukarı müzik ise ruhu etkiler (Soykan 2012: 30). Soykan biraz daha sert bir ifade ile: "Aslında aşağı müzik ve yukarı/yüksek müzik ayrımı yapmak bile fazladır. Müzik yalnızca yüksek müziktir". Soykan, aşağı müziğin, "müzik olmadığını (Soykan 2012: 31-32)" söyler.

Yine tek bir ölçüt üzerinden yapılan sınıflandırmalardan belki de en belirsiz alan olan beğeni estetik veya ideoloji ekseninde yapılır ki, en tartışmalı sınıflandırma da budur: "Güzel/iyi müzik" - "Çirkin/kötü müzik". Bu ayrımın kökeni çok eskilere dayanır: "Platon için iyi müzikler geleneğe ithaf edilmiş olanlardır, kötü müzikler ise esas olarak kulakların tatminini amaçlayan zamane müzikleridir (Akt: Canbay A. 2015: 246)". Say da bu tip bir yaklaşımla müzikleri sınıflandırır: "... şu tür müzik, bu tür müzik yoktur; iyi müzik, kötü müzik vardır (Say A. 2010:28)". Yöre, bu tip yaklaşımların sakıncalarından bahseder: "Müzik, akademisyenlerin müziğin türleri arasında kendi beğenilerine ve ideolojilerine göre öznel ayrımlar yapması ve hatta öğrencilerini de buna göre yönlendirmesi Türkiye'de sık görülen bir sorundur (Yöre 2012: 1201)". Yöre, bu tip yaklaşımlardaki sınıflandırmaların eğitimi de zedelediğini düşünür: "Özellikle sanatta/müzikte sınıflama olmaması kadar farklı sınıflamaların da birçok açıdan olmakla beraber daha çok eğitim-öğretim açısından, bir karmaşaya sebep olduğu deneyimlerle görülür (Yöre 2012: 1200). Bir müzik türüne iyi, güzel gibi kimi estetik değerlerle yaklaşmak müzikteki çeşitliliğin belirlenmesinde işimizi oldukça güçleştirir. Çünkü bu, estetik bir yargı olduğu kadar, aynı zamanda "dogmatik" bir yargıdır. Dogmanın bulunduğu yerde de bilimden bahsetmek mümkün değildir. Müzikçilerin çoğu belli bir amaç ve ideoloji doğrultusunda sınıflandırma yaparlar ve neyi sonuç olarak görmek istiyorlarsa stratejilerini buna göre belirlerler. Bu makalede vurgulanmak istenen şey, müziğin ideolojiden bağımsız olduğu değil, 
sınıflandırmanın temel dinamiklerinin stratejilerden ve ideolojiden olabildiğince uzak tutulmasına yönelik çabadır.

Kimi kaynaklarda ise sınıflandırmalarda birden fazla ölçüt kullanılır. Ancak bu sınıflandırmalarda da ölçütler birbirinden bağımsız bir şekilde değerlendirilmiştir. Akdoğu, birden fazla ölçüt kullananlardandır. Akdoğu belirlemiş olduğu her bir farklı ölçüt için ayrı ayrı sınıflandırma yapar. Akdoğu, müziği "üretim özellikleri ve toplumsal beğeni nedeniyle oluşan müzik ayrımı bakımından "Ulusal" ve "Uluslararası"; "bağımlı olduğu öğelere bakımından "Geleneksel" ve "Çağdaş"; "müziğin içeriğinin dünyasal ya da inançsal oluşu bakımından da "Dünyasal" ve "Inançsal” olarak sınıflandırır (Akdoğu 1996: 1-3).

Tanrıkorur da farklı ölçütler üzerinden sınıflandırma yapar ve sınıflandırma normları olarak beş madde belirler:

1. Genel Türüne Göre (Dini Müzik; Din Dışı Müzik)

2. İcra Türüne Göre (Ses Müziği; Çalgı Müziği)

3. Kullanıldığı Alana Göre (Askeri Müzik; Dini Müzik; Klasik Müzik; Halk Müziği; Eğlence Müziği)

4. İcra Edildiği Mekana Göre (Ordu Müziği; Saray Müziği; Cami Müziği; Tekke Müziği; Şehir Müziği; Köy Müziği)

5. İcra Tarzına Göre (Usûllü İcra; Usûlsüz İcra) (Tanrıkorur 2005:48).

Yukarıda ele alındığı gibi, müziksel literatürdeki sınıflandırmaları üç kategoride ele almak mümkündür:

1. Ölçütsüz (Gayr-i Sistematik) Sınıflandırmalar,

2. Tek Ölçütlü (Gayr-i Sistematik ve Sistematik) Sınıflandırmalar,

3. Çok Ölçütlü (Gayr-i Sistematik ve Sistematik) Sınıflandırmalar.

\section{Müzik Türleri Sınıflandırmasında Bir Model Önerisi}

Bu noktadan itibaren ben burada var olan müzik çeşitliliği içinden bir müziksel türü ayrıştırabilmek için yukarıda yer alan sınıflandırmalar dışında bir model öneriyorum. Bu model; ölçüt belirsizliği; belirlenen tek bir ölçüt ya da birbirlerinden bağımsız çok ölçüt yerine, "belirlenmiş olan birden fazla ölçütün ve bu ölçütler arasındaki ilişkiselliğinin" oluşturduğu bir yaklaşımı karşılıyor. Bu yaklaşım, hemen her müziksel tür için özel bilgiler üretmeye ve bu üretilen bilgiler ekseninde diğerlerinden farklı, özerk bir alan yaratılmasına imkân sağlamaktadır.

Temel müzik türleri için önerilen model, "kısmî olarak" Gültekin Oransay'dan (1976: 33-37) ilham ve temel alınmış ve geliştirilmiştir. Buna göre, temel bir müzik türü incelenirken dikkate alınması gereken ölçütler şunlardır: 
- Sosyolojik Bağlamı ${ }^{3}$ (Social Class \& Stratification, Scene): Ait Olduğu Toplum ve Toplum Katmanı Bağlamı: Bu ölçüt; hemen her müzik türünün ait olduğu bir toplumsal kesitin olduğunu vurgularken, müziğin toplumsallığı dışlamadan ele alınması gerekliliğini ortaya koyar.

- Oturtum ve Tını Bağlamı ${ }^{4}$ (Orchestration - Arangment \& Sound): Seslendirmede Kullanılan Ses Kaynakları ve Bunlardan Çıkan Tınısal Bütünlük: Bu ölçüt; hemen her müzik türünün seslendirildiği ses kaynakları ile ilgili müziğin karakteristiğini ortaya koyar.

- Çağ ve Zaman Bağlamı ${ }^{5}$ (Time \& Age): Ortaya Çıktığı, Ait Olduğu ve Devam Ettiği Zamansal Kesit Bağlamı: Bu ölçüt; her müzik türünün ortaya çıktığı ve icra edildiği bir zamansal kesite ait olduğunu ortaya koyar.

- Üslup ve Müziksel Doku Bağlamı ${ }^{6}$ (Style, Texture \& Repertory): Üslup/Biçem ve Ses Dizgesi Bağlamı: Bu ölçüt; üslup kavramının “müziksel davranışlar bütünü"7 olarak tanımlanmasından ötürü, her müzik türünde kendilik olarak kimi davranış modellerinin bulunduğunu ve ilgili üslubun seslendirilmesi için belirlenen ses dizgesinin varlığını ortaya koyar.

- Yer ve Mekân Bağlamı ${ }^{8}$ (Venue, Spatually): Üretildiği, Seslendirildiği ve Tüketildiği Müziksel Alan Bağlamı: Bu ölçüt; müzik türlerinin üretildiği ve seslendirildiği belirli yerler ve mekânlar bulunduğunu ortaya koyar. Burada "Makro" ve "Mikro" alanlar olarak ilgili müzik türleri iki farklı teritoryada değerlendirilir.

- İşlev, Repertuar ve Tema Bağlamı ${ }^{9}$ (Function, Repertory and Theme): Müziğin kullandığı Repertuar, Tema, Söz Unsuru'10: Bu ölçüt; müziğin neden, hangi amaçla üretildiği; ilgili müzik türüne ait olan dağarı ve dağarın merkezlendiği vokal temaları ortaya koyar.

Burada ölçütlerin bir bütünsellik oluşturduğunu ve bu bütünselliği oluşturan ölçütlerin arasında bir ilişkisellik olduğunu vurgulamak yerinde olacaktır. Yani buradaki temel yaklaşım, bu ölçütlerin varlığı ve birbiriyle olan ilişkiselliği üzerine inşa edilmiştir. Bu, aynı zamanda Gestalt prensibine dahil edilebilecek bir yaklaşım olarak da değerlendirilebilir. Gestalt prensibine göre de bir bütün, parçaların teke tek

${ }^{3}$ Oransay (1976: 33) Bu maddeyi: “Toplumla ve Toplum Katmanıyla İlgili Ayrımlar" olarak ele alır.

${ }^{4}$ Oransay (1976) Bu maddeyi: "Oturtumla İlgili Ayrımlar" olarak ele alır.

${ }^{5}$ Oransay (1976) Bu maddeyi: "Kişinin Yaşamıyla (Ortamla) İlgili Ayrımlar" olarak ele alır.

${ }^{6}$ Oransay (1976) Bu maddeyi "Örgü ve Üslupla İlgili Ayrımlar" olarak ele alır.

7 Konuyla ilgili olarak şu makale okunabilir: Ersoy, İlhan (2017). Üslup Kavramına Analitik Bir Bakış: Türkiye'de Geleneksel Müziklerde Performans Normları" Uluslararası Sosyal Araştırmalar Dergisi, Cilt 10 Sayı 49.

${ }^{8}$ Oransay (1976) Bu maddeyi: "Çağ ve Yerle Illgili Ayrımlar" olarak ele alır.

${ }^{9}$ Oransay (1976) Bu maddeyi: "Sanatsal Değer ve Gözdelikle İlgili Ayrımlar" olarak ele alır.

${ }^{10}$ Belli bir amaca ulaşmak için üretilen, seslendirilen ve tüketilen müzik. Burada absolut music, saf müzik, salt müzik kavramlarına karşıt bir yaklaşım vardır. 
birleşiminden daha fazlasını ifade eder. Aynı “Robert Lowie'nin kültürü bir parçalar ve yamalar birlikteliği (Akt: Monaghan \& Just 2013: 67)" olarak görmesi gibi.

Bu modelin temel çıkış noktası, her bir temel müzik türünün diğerlerine göre bu ölçütler ve bunların arasındaki ilişkisellik ekseninde farklılaştığı iddiasıdır.

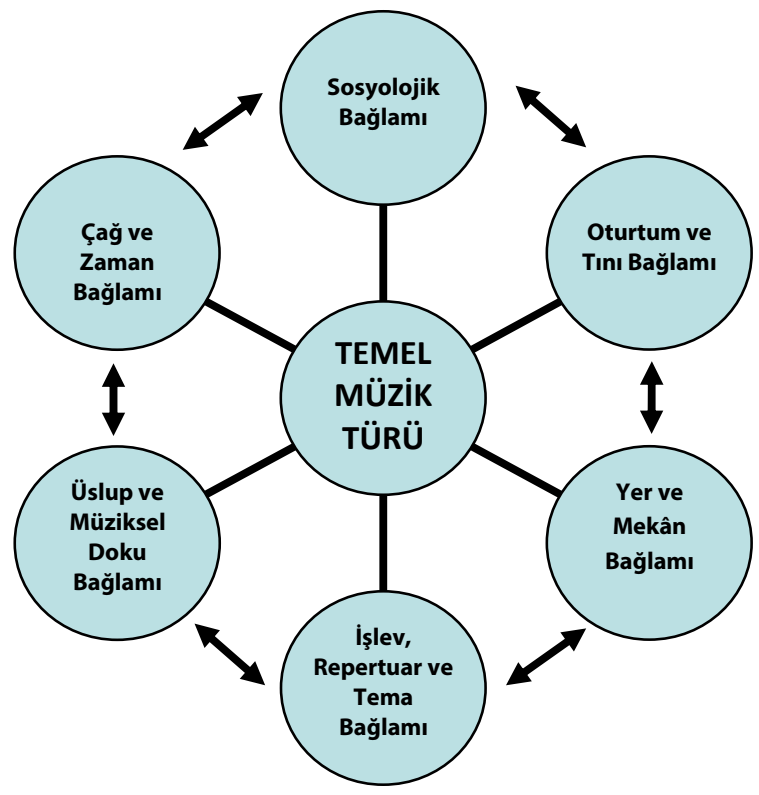

Şekil 3: Temel Müzik Türü Ölçütleri ve İlişkisel Ağı

Yukarıda belirtilen ölçütlerin her biri, her temel müzik türü için eşdeğer hacimde ya da önemde bilgi üretmeye uygun olmayabilir. Ya da kimi ölçütler ekseninde, iki farklı temel müzik türü için ortak veya benzer bilgi üretilebilir. Dolayısıyla temel müzik türlerinin iki farklı müzik türü olarak konumlandırılabilmesi için her bir ölçüt üzerinden mutlak bir biçimde farklılaşmasını beklemek gerekli ve zorunlu bir koşul değildir. Bu ölçütlerin arasındaki ilişkisellik daha önce de vurgulanmıştı. Dolayısıyla bu modelde, ölçütlerin arasındaki ilişkisellik ve bütünlük bakımından müzik türlerini konumlandırabileceğimizi tekrar hatırlamak isterim. Buradan hareketle modelin uygulanması sonucunda: "Halk müzikleri"; "Sanat Müzikleri" ve "Popüler Müzikler", temel müzik örnekleri olarak karşımıza çıkar"1. Buraya kadar önerilen ölçütler, her ne kadar temel müzik türleri öncellenerek açıklanmış olsa da bunlar "alt türler" için de kullanılması gereken ölçütlerdir. Temel

\footnotetext{
${ }^{11}$ Modelin uygulanması, yani ölçütler üzerinden gerçekleştirilecek olan irdeleme bir başka makalede ele alınacaktır.
} 
müzik türleri için etkisiz kalan ancak Türk sanat müziği temel türüne ait peşrev, Türk halk müziği temel türüne ait zeybek vb. gibi tüm alt türler için ise, son derece belirleyici bir etki yaratan iki farklı ölçütün değerlendirmeye dahil edilmesi gereklidir. Bu ölçütler şunlardır:

1. Ritimsel Katmanlar (tartım, düzüm, atım, vb.)

2. Biçim (şekil, form)

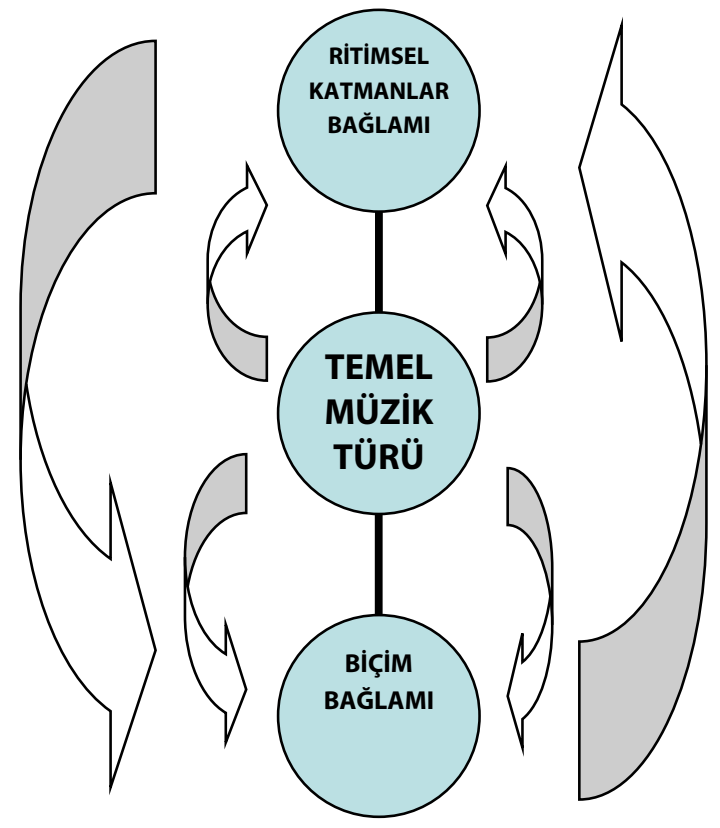

Şekil 4: Alt Tür/Yaratı Türü Ilişkisel Ağı

\section{Ritimsel Katmanlar Bağlamı}

Müzik, zamandan bağımsız düşünülemez. Müziğin zaman içindeki konumunu belirginleştiren en temel bileşeni ise ritimdir. Ritim, tanımı itibariyle zaman içindeki akış ve devinim bütünlüğüdür. Ritim bu bakımdan müzik kültürlerine göre değişkenlik gösteren usûl, tartım, atım, ölçü, vb. gibi içinde çok katmanlı bir yapı barındıran kapsayıcı, "şemsiye" bir kavramdır. Türk müziklerinde kavram kimi zaman bu katmanlardan yalnızca birine indirgenerek kullanılırken; kimi zaman da kapsayıcılığı özelliği nedeniyle, bütünselliğe atıfta bulunarak kullanılır.

Her müziksel türün onu diğerlerinden farklılaştıran bir ritimsel yapısı vardır. Dolayısıyla bu ritimsel yapılar, alt türler çerçevesinde önemli bir işlev yüklenirler. 


\section{Biçim Bağlamı}

Biçim, bir nesnenin dış çizgileri bakımından niteliği, dıştan görünüşü, şekli ve eşkâlidir. Çoğu sanat dalında olduğu gibi müziğin de bir biçimi vardır. Ancak resim ve heykel gibi kimi görsel sanatlar somut bir biçim içerirken; müzikte bu soyut bir hal alır. Fakat bu soyutluk, müzikte biçimsel (şekilsel) bir yapının olmadığı anlamına gelmez. Müziği diğer sanatsal üretimlerden ayıran temel fark, biçimin tespit edilmesinde görselliğin değil, işitselliğin ön planda olmasıdır.

Müzikte biçim, aynı ritim kavramı gibi içinde onu bütünleştiren kimi katmanlara sahiptir. Bu biçimsel katmanların irdelenmesi her ne kadar biçim konusunun daha iyi anlaşılması için önemli ve zorunlu olsa da biçime ilişkin kavramların ${ }^{12}$ irdelenmesi bu makalenin sınırlarını aşar.

Biçim konusu özellikle Batı sanat müziğinde keskin sınırları olan ve tür olarak müziği farklılaştıran en temel ölçütlerden biri olarak görülür. Oysa her müzik kültürünün kendi iç dinamiklerine göre değerlendirildiğinde bu farklı sonuçlar doğurabilir. Örneğin, Türk müziğinde biçim konusu, Batı sanat müziğinde olduğu kadar başat konumda değildir. Önerilen modelde de görüleceği üzere Türk müziğinde tür tasniflerinde biçim ölçütü, diğer ölçütler kadar bir konum elde etmektedir. Dolayısıyla müzikte biçim konusunu tek başına belirleyici bir parametre olarak ele almak yanıltıcı olacaktır.

\section{Gizil Unsurlar}

Yukarıda belirlenmiş olan modelin içinde kesin bir ölçüt olarak yerleştirilemeyen ancak kimi müziksel türlerde karakteristik bir kimlik alanı yaratma potansiyeli taşıyan gizil unsurlar bulunur. Burada bu unsurların varlığını kabul ederek, hemen her müzik türünün kendilikleriyle ilişkili ve sınırlılıkta olması nedeniyle modelin içinde yer verilmesi gereksiz görülmüştür.

Gizil unsurlara en iyi örnek halk müzikleri ile sanat müzikleri arasındaki farkı belirginleştiren "bilinç" kavramıdır. Burada kullanılan "bilinç" kavramının, herhangi bir yergi içermediğini, bir kavramsal kullanım olduğunun altını çizmek, kimi müzikçilerin alınmasının önüne geçecektir diye umuyorum. Zira kimi zaman içine dahil olunan müzik türlerine ilişkin realiteler, ilgili mensupları rahatsız edebilmektedir. Çünkü kimi müzikçiler için mensubiyeti bulunan müziğe bir kutsallık atfedilebilmektedir. Kutsallık, bilindiği üzere zihinsel değil, daha çok duygusal ve ruhsal bir alana tekabül eder. Burada bilinç kavramının kelime karşılığı olarak "farkındalık" düşünülebilir. Yani yapılan işin bilinçli (yani farkında olunarak) yapıldığını anlatır. Bu anlatımda hiçbir biçimde "estetik" ile bir ilişkilendirme mümkün değildir. Yani bilinçli yapılan müziklerin "güzel"; diğerlerinin "çirkin" olduğu gibi "garabet bir algı" ciddi bir yanılsamadır.

\footnotetext{
${ }^{12}$ Motif, cümlecik, cümle, bölüm, periyod gibi kimi biçimsel kavramlar bu makalenin hacmini aşacağı için bu makalede ele alınmamıştır.
} 
Bilinç ekseninde bakınca müzikte iki farklı düzlem vardır. İlk düzlem bilinçliliği; ikinci düzlem ise yarı bilinçliliği ya da bilinçsizliği kuşatır. Bilinçlilik müzikte, pratiğin söylemsel olarak iletişim yoluyla ve kavramsal $\operatorname{araçlar}^{13}$ yardımıyla ifade edilebilen kesiti karşılar. Yarı bilinçlilik ya da bilinçsizlik ise, kavramsal söylemlerin varlığından çok, semboller ve kodlar aracılığıyla, içduyumsal (tacit) bir düzlemi kuşatır.

Gizil unsurlar özelinde bir başka örneği, "elektronik müzik"ten verebiliriz. Elektronik müziklerde besteci ve yorumcu diye iki ayrı kişi ya da kişiler yoktur. Bu o müziğin doğasına aykırıdır. Bunun yanı-sıra birçok farklı müzik nota ile icra edilirken, elektronik müzik buna ihtiyaç duymaz. "Klasik müzik anlayışında en güzel sese ulaşma gayesi cazda o kadar öncelikli bir unsur değildir, önemli olan ifadeyi anlık olarak yaratmaktır (Kandemir 2012: 263)".

Türk halk müziğinde şiirsel yapının çoğu zaman bir tür adına dinamik oluşturduğunu; ilgili müzik türünün adını, onun sözel yapısından aldığını görebiliyoruz. Örneğin türkü, bir müziksel tür olmaktan çok, şiirsel bir türdür. Ya da varsağı, koşma ${ }^{14}$, kayabaşı, gibi kimi şiirsel yapıların, (bir yanılsama olarak da olsa) bir tür adı olarak müziksel zemine taşındığını görüyoruz. Bu kimi zaman sanat müziğindeki "türkü formu" ifadesinde de karşılık bulur. Sözel yapının halk şairlerinden alınması ilgili müziğin türkü olarak ya da türkü formu olarak adlandırmada yeterli olarak görülebilir. "Karacaoğlan, Yunus Emre, Gevherî, Emrah, Aşık Ömer gibi halk ozanları da bestekarlarımızı etkilemiş, türkü tarzında şarkıların doğuşunu hazırlamışlardır (Yavaşça 2002: 301)". Yine sanat müziğinde Divan ${ }^{15,}$ Semai ${ }^{16,}$ Kalenderi $^{17}$ gibi türleştirmiş, tür olarak kabul edilmiş müzikleri de örnek olarak verebiliriz.

"Görünmeyen perdeler" bir başka gizil unsur olarak değerlendirilebilir. Türk sanat müziğinde her ne kadar ses dizgesi belli ise de uygulama alanı, teorik alanla çatışır ve konuyu gizil bir unsur haline getirir.

\section{SONUÇ}

Müzik, çok unsurlu, karmaşık bir fenomendir. Bu fenomenin kendini oluşturan bileşenlere ve bileşenlerin ölçütlerine yönelerek irdelenmesi onun daha iyi anlaşılmasını sağlayacaktır.

Bu makale, keyfi ve ideolojik sınıflandırmaları değersizleştirmeye yönelik bir çabanın yansımasıdır. Buna yönelik önerilen modelde müzikte tür kavramının indirgemeci, monolojik bir ele alış ile anlaşılamayacağı, müziklerin çoklu dinamikleri ve bağlamları ret etmeyeceği vurgulanmıştır. Eğer müzikteki çeşitliliğin bir biçimde

\footnotetext{
13 Kavramsal araçlar bakımından bakıldığında; sanat müziklerinde: İlgili müzik mensuplarınca müzik üzerine yazılı kaynakların oluşturulduğu (tarihsel, akustik, kuramsal) ve kavramsal-kuramsal tartışmaların oluşturulduğu bir alan yaratılırken; halk müziklerinde bu alan tamamen -dışarıdan- müzik araştırmacıları tarafından eklemlenmiştir, halk müziklerinin doğasında ve iç dinamiğinde böyle bir edim yoktur.

${ }^{14}$ Hece sayısı 11 'li olan şiirsel yapı.

${ }^{15}$ Aruz yazılan örneklerinin: "Failâtün / Failâtün / Failâtün / Failün"

${ }^{16}$ Aruz örneklerini: "Mefailün / Mefailün" kalıbında yazılmıştır.

${ }^{17}$ Aruz kalıbı "Mefailün / Mefailün / Mefailün / Failün”.
} 
sistematize edilmesi gerekiyorsa, bu bilimsel ve meşru araçlar yoluyla gerçekleştirilmelidir.

\section{KAYNAKÇA}

Akdoğu, Onur (1996). Türk Müziğinde Türler ve Biçimler. İzmir: Ege Üniversitesi Basımevi.

Arslan, Ahmet (2009). Felsefeye Giriş. Ankara: Adres Yayınları.

Arslan, Hüsamettin (2007). Epistemik Cemaat Bir Bilim Sosyolojisi Denemesi. İstanbul: Paradigma Yayıncılık.

Becker, S. Howard (2013). Sanat Dünyaları (Çev: Evren Yılmaz). İstanbul: Ayrıntı Yayınları.

Berendt, E. Joachim (2003). Caz Kitabı. İstanbul: Ayrıntı Yayınları.

Bilgin, Nuri (2003). Sosyal Psikoloji Sözlüğü Kavramlar Yaklaşımlar. İstanbul: Bağlam Yayıncılık.

Bulanık, Fikri (2005). Dünyadan Müzikler. İzmir: Kanyılmaz Matbaası.

Canbay, Alaattin (2015). “Türkiye'de Müzik Türleri ve Gelişimleri”. Z. v. Nacakçı içinde, Müzik Kültürü ss. 199226. Ankara: Pegem Akademi.

Erol, Ayhan (2009). Müzik Üzerine Düşünmek. İstanbul: Bağlam Yayınları.

Ersoy, IIIhan (2017). Üslup Kavramına Analitik Bir Bakış: Türkiye'de Geleneksel Müziklerde Performans Normları. Uluslararası Sosyal Araştırmalar Dergisi, ss. 302-314.

Hodeir, Andre (1971). Müzikte Türler ve Biçimler. İstanbul: Maarif Basımevi.

Kaemmer, E. John (1993). Music in Human Life Anthropological Perspectives on Music. Austin: University of Texas Press.

Kandemir, Orhan (2012). "Yitik Zamanın İçinde: Caz". Doğu Batı Sayı 62, ss. 261-268.

Kenny, G. Michael \& Smille, Kirsten (2015). Antropolojiye Giriş. (S. Torlak, Çev.) Ankara: Dipnot Yayınları.

Kongar, Emre (2007). Toplumsal Değişme Kuramları ve Türkiye Gerçeği. İstanbul: Remzi Kitabevi.

Mardin, Şerif (2033). İdeoloji. İstanbul: İletişim Yayıncılık.

Monaghan, John \& Just, Peter (2013). Sosyal ve Kültürel Antropoloji (Çev: Hakan Gür). Ankara: Dost.

Oransay, Gültekin (1976). Müzik Tarihi. Ankara: Yaykur Açık Yükseköğretim Dairesi.

Özbudun, Sibel \& Şafak, Balkı \& Altuntek, N. Serpil (2007). Antropoloji Kuramlar / Kuramcılar. Ankara: Dipnot Yayınları.

Rice, Timothy (2002). "Etnomüzikolojinin Yeniden Şekillenmesine Doğru”. Folklor Edebiyat, Sayı 31, ss.133-150.

Salcı, Vahid Lütfü (1938). "Bela Bartok'un Konferansları: Gizli Halk Musikisi”. Ülkü, ss. 113-123, http://www.folkloredebiyat.com/gizlimusiki.html (Erişim Tarihi: 02.10.2017)

Say, Ahmet (2008). Müzik Nedir, Nasıl Bir Sanattır? İstanbul: Evrensel Basım Yayın.

Say, Ahmet (2010). Müzik Yazıları. Ankara: Müzik Ansiklopedisi Yayınları.

Sezikli, Ubeydullah (2007). Abdülkadir Meragi ve Camiul-Elhan'. İstanbul: MÜSBE Yayınlanmamış Doktora Tezi.

Soykan, Ömer Naci (2012). "Müzik Nedir? Felsefi Bir Araştırma”. Doğu Batı Sayı 62, ss 29-42.

Tanrıkorur, Cinuçen (2005). Osmanlı Dönemi Türk Musikisi. İstanbul: Dergâh Yayınları.

Uçan, Ali (2005). Müzik Eğitimi. Ankara: Evrensel Müzikevi.

Yavaşça, Alâeddin (2002). Türk Mûsıkîsi'nde Kompozisyon ve Beste Biçimleri. İstanbul: Türk Kültürüne Hizmet Vakfı.

Yıldırım, Cemal (2010). Bilim Felsefesi. Ankara: Remzi Kitabevi.

Yöre, Seyit (2012). "Bruno Nettle ile Etnomüzikolojik Değerlendirmeler". International of Human Sciences, ss. 1189-1205.

Yücel, Haluk (2007). Türkiye'de Din ve Dindışı Müziklerinin Karşılaştırılmalı Araştırması. İstanbul: Yöntem Yayınları. 